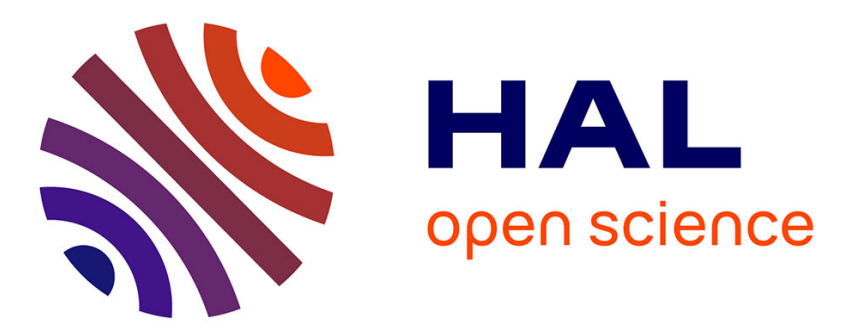

\title{
Types I and II interferons upregulate the costimulatory CD80 molecule in monocytes via interferon regulatory factor-1
}

\author{
B. Bauvois, J. Nguyen, R. Tang, C. Billard, J.-P. Kolb
}

\section{- To cite this version:}

B. Bauvois, J. Nguyen, R. Tang, C. Billard, J.-P. Kolb. Types I and II interferons upregulate the costimulatory CD80 molecule in monocytes via interferon regulatory factor-1. Biochemical Pharmacology, 2009, 78 (5), pp.514. 10.1016/j.bcp.2009.05.005 . hal-00497271

\section{HAL Id: hal-00497271 \\ https://hal.science/hal-00497271}

Submitted on 3 Jul 2010

HAL is a multi-disciplinary open access archive for the deposit and dissemination of scientific research documents, whether they are published or not. The documents may come from teaching and research institutions in France or abroad, or from public or private research centers.
L'archive ouverte pluridisciplinaire HAL, est destinée au dépôt et à la diffusion de documents scientifiques de niveau recherche, publiés ou non, émanant des établissements d'enseignement et de recherche français ou étrangers, des laboratoires publics ou privés. 


\section{Accepted Manuscript}

Title: Types I and II interferons upregulate the costimulatory CD80 molecule in monocytes via interferon regulatory factor-1

Authors: B. Bauvois, J. Nguyen, R. Tang, C. Billard, J.-P. Kolb

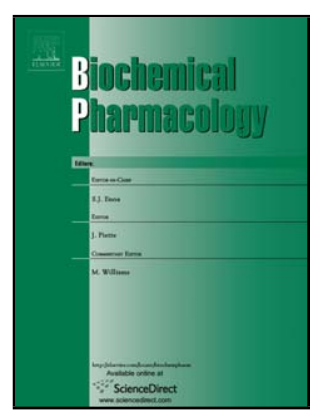

PII:

S0006-2952(09)00371-2

DOI: doi:10.1016/j.bcp.2009.05.005

Reference: BCP 10175

To appear in: $\quad B C P$

Received date: $\quad$ 10-3-2009

Revised date: $\quad 30-4-2009$

Accepted date: $\quad$ 4-5-2009

Please cite this article as: Bauvois B, Nguyen J, Tang R, Billard C, Kolb J-P, Types I and II interferons upregulate the costimulatory CD80 molecule in monocytes via interferon regulatory factor-1, Biochemical Pharmacology (2008), doi:10.1016/j.bcp.2009.05.005

This is a PDF file of an unedited manuscript that has been accepted for publication. As a service to our customers we are providing this early version of the manuscript. The manuscript will undergo copyediting, typesetting, and review of the resulting proof before it is published in its final form. Please note that during the production process errors may be discovered which could affect the content, and all legal disclaimers that apply to the journal pertain. 


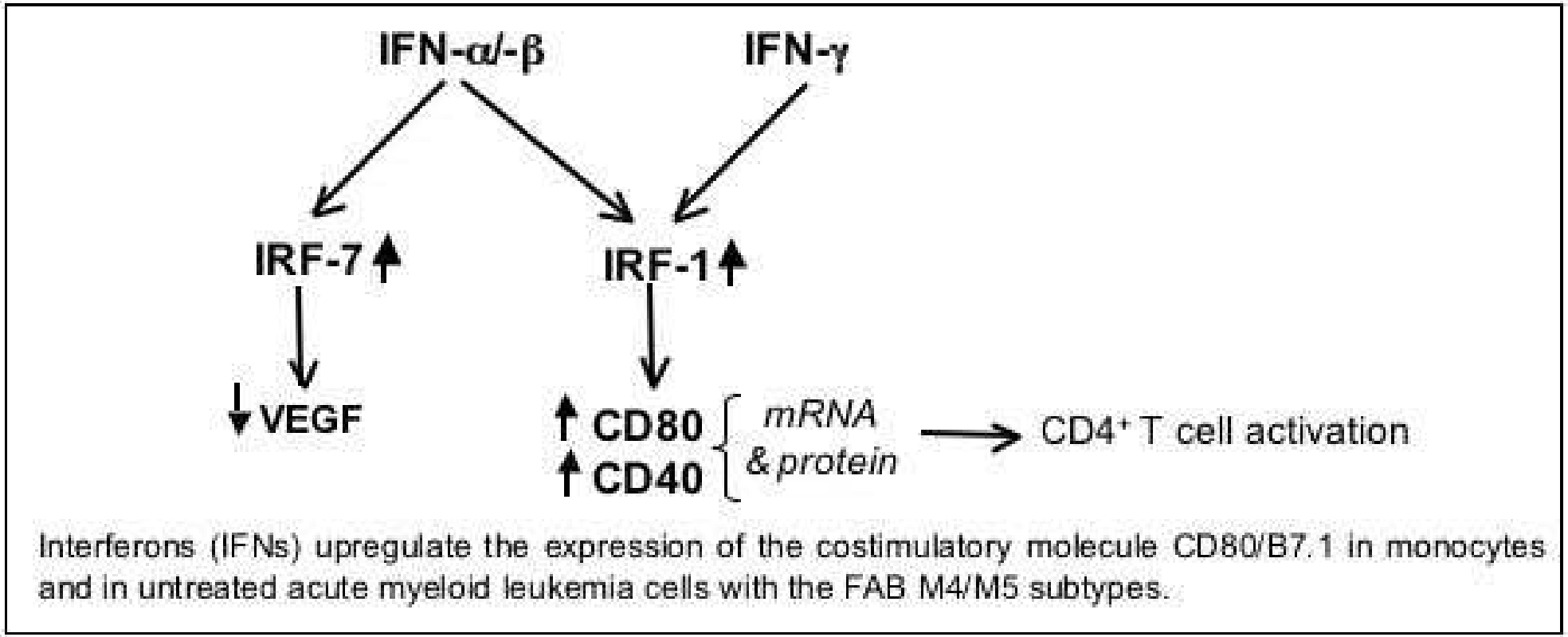


Types I and II interferons upregulate the costimulatory CD80 molecule in monocytes via interferon regulatory factor-1

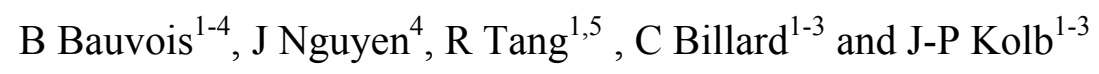

${ }^{1}$ INSERM, U872, Paris, F-75006 France ; ${ }^{2}$ Centre de Recherche des Cordeliers, Université Pierre et Marie Curie, UMRS 872, Paris, F-75006 France $;{ }^{3}$ Université Paris Descartes, UMR S 872, Paris, F-75006 France ; ${ }^{4}$ UMR 7131/CNRS Paris 5, Paris, F-75014 France; ${ }^{5}$ Assistance Publique - Hôpitaux de Paris, Hôpital Hôtel Dieu, Paris, F-75004 France.

Corresponding author : Dr. Brigitte Bauvois, Centre de Recherches des Cordeliers UMRS 872 - Equipe 18, 15 rue de l'Ecole de Médecine, 75270 Paris Cedex 06, France.

Phone/Fax: + 33 (0)1 432563 44; E-mail: brigitte.bauvois@crc.jussieu.fr 


\section{ABSTRACT}

CD80/B7.1 expressed on monocytes plays a prominent role in the activation of T-cellmediated immunity and its level is reduced in monocytes from cancer patients. Type I ( $\alpha / \beta)$ and type II $(\gamma)$ IFNs are widely administered as adjuvant therapy. We show here that both classes of IFNs upregulate CD80 mRNA and protein in primary monocytes ex vivo. The stimulatory action of IFN- $\alpha / \beta$ on CD80 is accompanied by the activation of both interferon regulatory factors IRF-1 and IRF-7, whereas IFN- $\gamma$ stimulating effect is associated only with IRF-1 induction. IFNs concomitantly upregulate the transcription of CD40 costimulatory molecule whose activation is known to require IRF-1. In monocytic U937 cells, IRF-1 is activated by IFN- $\gamma$ but not by IFN- $\alpha / \beta$, whereas it is the reverse for IRF-7; in the latter cells, only IFN- $\gamma$ is capable of stimulating CD80 transcription emphasizing the essential role of IRF-1. Moreover, siRNA against IRF-1 prevents IFN- $\gamma$-mediated CD80 activation. In AML cells, IFNs upregulate CD40, CD80 and IRF-1 in the FAB M4/M5 subtypes but not in the less differentiated M1/M2 subtypes. Monitoring the expression of CD80 on AML cells and its modulation by IFNs could help to predict the patients more susceptible to benefit from therapeutic strategies aimed at eliciting specific $\mathrm{T}$ cell responses to leukemia-associated antigens.

Keywords : B7.1; antigen presenting cells; IRF-1; acute myeloid leukemia. 


\section{Introduction}

To achieve full T-cell activation and recognition with the major histocompatibility complex (MHC) class I/II on antigen presenting cells (APC) by the T cell receptor, a second signal is required $[1,2]$. This is provided by antigen-independent interactions between cosignaling molecules on T cells and their respective ligands on antigen presenting cells or APC $[1,2]$. Costimulatory molecules including CD40-CD154 and CD80-CD28 interactions, play a prominent role in the initiation of immune responses [2, 3]. Monocytes as APC, express the CD40 and CD80 molecules [1-3]. Of importance, both antigens are either undetected or detected at low levels in most human acute myeloid leukemia (AML) blasts [4-8]. Moreover, very low levels of CD80 are observed on circulating monocytes from children with various cancers [9] and on monocytes infiltrating colorectal carcinomas [10]. This deficient expression of CD40 and CD80 reflects an ineffective antigen-presenting function of these cells. Yet, AML cells transfected with the CD80 gene are capable of enhancing T cell effector function [11-13]. As an alternative approach, human CD80 immunoglobulin $\mathrm{G}$ (IgG) fusion protein targeted to the high-affinity $\mathrm{Fc}-\gamma$ receptor (CD64) expressed on AML blasts has been used to restore its expression on these cells, thereby enhancing their immunogenicity for autologous T cells [14]. Therefore, understanding the molecular mechanisms involved in the upregulation of cosignaling molecules may be helpful in order to stimulate $\mathrm{T}$ cell-mediated immunity.

The interferon (IFN) family includes type I $(\alpha / \beta)$ and type II $(\gamma)$ IFNs that are implicated in the resistance of mammalian hosts to pathogens and in the modulation of antiviral, antitumoral and immune responses [15]. The efficacy of IFNs has been exploited in maintenance therapy for patients with cancer and viral related diseases $[16,17]$. Type I and type II IFNs, by respectively binding type I and type II IFN-receptors, activate both similar 
and dissimilar Jak/Stat signal pathways [18-20]. IFN- $\alpha /-\beta$ stimulation leads to the formation of two transcriptional activator complexes, a homodimer of signal transducer and activator of transcription (Stat)1 and IFN-stimulated gene factor 3 (ISGF3) which comprises Stat1, Stat2 and IRF-9 (or p48) [21]. Stat1 homodimer binds IFN- $\gamma$-activated site (GAS) motifs in promoter regions of various genes, such as interferon regulatory factor-1 (IRF-1) gene [20, 21]. ISGF3 binds to IFN-stimulated response element (ISRE) promoter regions in ISREcontaining genes, including IRF-7 gene, and activates their transcription [21]. IFN- $\gamma$ signals mainly through Stat 1 homodimer [20, 21]. In addition, IFN- $\alpha$ and IFN- $\beta$ may exhibit separate bioactivities through their different affinities and rate constants of interaction with IFN type I receptor subunits $[22,23]$.

Previous studies have shown that TNF- $\alpha$, IFN- $\beta$ and IFN- $\gamma$ upregulate CD40 expression in various cell types including monocytes $[24,25]$. NF- $\mathrm{kB}$ and IRF-1 have been implicated in the regulation of CD40 expression [26-28]. Some data have shown that CD80 expression in monocytes could be enhanced by IFN- $\gamma[29,30]$, IFN- $\beta$ [25] and TNF- $\alpha[31]$ but the molecular mechanisms involved are not elucidated. In the present work, we studied the transcriptional regulation of CD80 in response to IFNs in monocytes, in the monocytic U937 cell line and in AML blasts. We investigated the potential involvement of transcription factors IRF-1 and IRF-7 with regard to their key roles in IFN signalling. Our results show the essential role of IRF-1 in the coordinated upregulation of CD40 and CD80 genes and this may have implications in the context of therapeutic potential of IFNs. 


\section{Materials and Methods}

\subsection{Reagents and antibodies}

Ficoll-Hypaque was from GE Healthcare France (Aulnay-sous-Bois, France). RPMI 1640 medium, L-glutamine, sodium pyruvate and fetal calf serum (FCS) (lipopolysaccharide levels $<0.1 \mathrm{ng} / \mathrm{mL}$ ) were from Gibco (Paisley, Scotland). Gentamycin was from Flow laboratories (Rockwell, MD, USA). Recombinant human IFN- $\gamma\left(2 \times 10^{7} \mathrm{U} / \mathrm{mg}\right)$ was supplied by R\&D (Abingdon, UK). Recombinant human IFN- $\alpha 2 \mathrm{a}\left(2 \times 10^{8} \mathrm{U} / \mathrm{mg}\right)$ and IFN- $\beta\left(2 \times 10^{8} \mathrm{U} / \mathrm{mg}\right)$ were provided by Hoffman-La Roche (Basel, Switzerland) and Ares-Serono (Geneva, Switzerland) respectively. Recombinant human TNF- $\alpha\left(10^{3} \mathrm{U} / \mathrm{mg}\right)$, neutralizing anti-human TNF- $\alpha$ (goat IgG, clone AF-210-NA), anti-CD80-PE (mouse IgG1, clone 37711.111) and anti-CD14-FITC (mIgG2a, clone 134620) were from from R\&D (Abingdon, UK). Anti-CD40-FITC (mIgG1, clone 5C3) was from Becton Dickinson (San Jose, CA, USA). IgG2a-FITC (clone U7.27) and IgG1-PE (clone 679.1Mc7) were from Beckman-Coulter (Luminy, France). IgG1-FITC (clone F1c2855), goat IgG (clone 0365C-2028), anti-IRF-1 (rabbit polyclonal IgG, clone C20), anti-IRF-7 (rabbit polyclonal IgG, clone H-246) and IRF-1 siRNA were from Santa Cruz Biotechnology (Santa Cruz, CA, USA). Anti-actin (mIgG1, clone C4) was from ICN Biomedicals (Ohio, USA). Negative control siRNA was from Ambion (Austin, TX, USA).

\subsection{Blood samples}

Peripheral blood samples of 12 patients with acute myeloid leukemia (AML) were obtained, after their informed consent, in agreement with the revised Helsinki protocol rules, from the tumour bank of the Hôtel-Dieu hospital (Paris). AML cells were defined according to cytological criteria based on the classification of the French-American-British (FAB) committee. They included 4 M5 cases (monoblast/monocyte), 2 M4 (myelomonocyte), 2 M2 
and 4 M1 (myeloblast). Blood samples from 27 unmatched healthy volunteers were purchased from the Etablissement Français du Sang, EFS.

\subsection{Cells isolation and cultures}

Primary monocytes from normal blood donors were isolated by Ficoll-Hypaque density gradient $(1.077 \mathrm{~g} / \mathrm{mL})$ centrifugation and adherence as described [32]. As assessed by flow cytometry analysis of the CD14 antigen, adherent cells contained $\geq 95 \%$ monocytes. Mononuclear cells from AML patients were isolated on Ficoll-Hypaque gradient in the same way as described above for primary monocytes. After counting, the isolated cells were directly processed and plated at a density of $1 \times 10^{6} / \mathrm{mL}$ in RPMI 1640 medium supplemented with $2 \mathrm{mM}$ L-glutamine, $1 \mathrm{mM}$ sodium pyruvate, $40 \mu \mathrm{g} / \mathrm{mL}$ gentamycin containing $10 \% \mathrm{FCS}$. These cells were cultured at $37^{\circ} \mathrm{C}$ for for various periods of time in a $5 \% \mathrm{CO}_{2}$ humidified atmosphere, in the absence or presence of varying concentrations of IFNs.

\subsection{U937 cell line and IRF-1 siRNA transfection}

The monocytic cell line U937 obtained from American Tissue Cell Culture (Manassas, VA, USA) was grown in RPMI 1640 medium supplemented with glutamine, sodium pyruvate, gentamycin and $5 \% \mathrm{FCS}$ at $37^{\circ} \mathrm{C}$. Cells $\left(2 \times 10^{5} / \mathrm{mL}\right)$ were cultured in the absence or presence of IFNs $(1000 \mathrm{U} / \mathrm{mL})$ for $24 \mathrm{~h}$. For transfection, U937 cells $\left(1 \times 10^{6}\right)$ in $100 \mu$ l solution kit V were transfected with $50 \mathrm{nM}$ IRF-1 small interfering RNA (siRNA) or with negative control siRNA using an Amaxa nucleofector according to the manufacturer's protocol (program U13). Cells were then plated in 6-well plates for $18 \mathrm{~h}$, followed by stimulation with IFN- $\gamma$ $(500 \mathrm{U} / \mathrm{mL})$ for additional $18 \mathrm{~h}$. Cells were then harvested, immunostained with anti-CD80 and analyzed for CD80 expression by flow cytometry. 


\subsection{Flow cytometry analysis}

Intact cells were immunostained as described [32]. Coexpression of CD40 and CD80 on monocytes and AML cells was determined by two-color staining with fluorescein isothiocyanate (FITC) and phycoerythrin (PE)-labeled antibodies. A total of 20,000-40,000 events were analyzed with a FACS flow cytometer analyzer (Coulter-Beckman, Luminy, France). Values are given as percentages of positive cells and median fluorescence intensity (MFI) obtained by subtracting the peak channel number of the negative control from the peak channel number of the corresponding antibody.

\subsection{RT-PCR analysis}

RNA extraction and cDNA synthesis were conducted as described [33]. Specific human primers were chosen according to published sequences [33-36] and synthesised by SigmaProligo (Sigma-Proligo France): CD80, 5'-TTG GAT TGT CAT CAG CCC TGC-3' (forward) and 5'-ATT TTC TCC TTT TGC CAG TAG-5' (reverse); IRF-1, 5'-CTT AAG AAC CAG GCA ACC TCT GCC TTC-3' (forward) and 5'-GAT ATC TGG CAG GGA GTT CAT G-3' (reverse); IRF-7, 5'-TGC AAG GTG TAC TCG GAG-3' (forward) and 5'-TCA AGC TTC TGC TCC AGC TCC ATA AG-3' (reverse); VEGF, 5'- ACA TCT TCC AGG AGT ACC CTG ATG AG-3' (forward) and 5'- GCA TTC ACA TTT GTT GTG CTG T-3' (reverse) ; 32-microglobulin, 5'-CAT CCA GCG TAC TCC AAA GA-3' (forward) and 5'-GAC AAGT CTG AAT GCT CCA C-3' (reverse). Specific primers for CD40 were from R\&D (Abingdon, UK). The annealing temperature of CD40 primer was $55^{\circ} \mathrm{C}$ and $57^{\circ} \mathrm{C}$ for the others. PCR products were visualized by electrophoresis in $2 \%$ agarose gel containing $0.2 \mu \mathrm{g} / \mathrm{mL}$ ethidium bromide (Euromedex, Souffelweyersheim, France). Equivalent loading of lanes 
was controlled by measuring the $\beta 2$-microglobulin transcripts. The NIH Image 1.63 software was used for the analysis and the quantification of the bands after acquisition in an Appligen densitometer (Oncor).

\subsection{Immunoblot analysis}

Total cell extracts were prepared, separated on $12 \%$ polyacrylamide-SDS gels, transferred to nitrocellulose (Schleicher \& Schuell France) and blotted [37] with Abs for IRF-1 (rabbit polyclonal IgG), IRF-7 (rabbit polyclonal IgG) or actin (mIgG1) as described previously [37] using the chemiluminescence technique developed by Santa Cruz. Immunoreactive protein bands were detected by autoradiography on Hyperfilms (Kodak) and the bands were acquired with an Appligen densitometer (Oncor).

\subsection{Enzyme-linked immunosorbent assays}

The culture supernatant fractions from cells $\left(10^{6}\right.$ cells $\left./ \mathrm{mL}\right)$ cultured for 3 days in the absence or presence of IFNs were harvested under sterile conditions and frozen before CD80 and MMP-9 contents were determined using commercial ELISA kits respectively provided by Bender MedSystems (Vienna, Austria) and R\&D (Abingdon, UK). Controls included FCSsupplemented RPMI 1640 medium alone incubated under the same conditions. The concentrations were calculated after substraction of the control values. Detection level was $0.1 \mathrm{ng} / \mathrm{mL}$ for CD80 and $1 \mathrm{ng} / \mathrm{mL}$ for MMP-9.

\subsection{Data analysis}

Results from $\mathrm{n}$ independent experiments were analyzed for statistical significant differences using the Student's t-test. They are expressed as the mean \pm SD. $P$ values below 0.01 were considered as statistically significant. 


\section{Results}

\subsection{Type I and II IFNs upregulate surface CD80 expression on monocytes}

As assessed by immunostaining and flow cytometry, freshly isolated monocytes cultured in medium alone for $18 \mathrm{~h}$ expressed low levels of CD80 surface protein (Figure 1A). Exposure to IFNs $(1000 \mathrm{U} / \mathrm{mL})$ resulted in a marked increase in the percentage of $\mathrm{CD} 80^{+}$monocytes (Figure 1A), as well as in CD80 median fluorescence intensity (Figure 1B). To investigate the kinetics of the upregulation of CD80 by IFNs, the effects of various times of stimulation (18, 24, 48 and $72 \mathrm{~h}$ ) were compared. Optimal enhancement of CD80 expression in response to IFNs was already seen at $24 \mathrm{~h}$ after stimulation and high levels of CD80 expression were maintained for $72 \mathrm{~h}$ (Figure 2A). The dose-response was analysed by adding varying concentrations of IFNs (10-2000 U/mL) Optimal upregulation of CD80 by IFNs was almost observed at $2000 \mathrm{U} / \mathrm{mL}$ (Figure $2 \mathrm{~B}$ ). These data also indicate that roughly similar doseresponses and kinetics were observed for both type I and type II IFNs.

To investigate whether the enhancement of surface CD80 was associated with the release of soluble CD80, we measured CD80 protein in monocyte supernatants by ELISA. No detectable levels of CD80 were found (data not shown), suggesting that surface CD80 upregulation was not accompanied by CD80 release to the extracellular compartment.

\subsection{Concomitant upregulation of cell surface CD40 and CD80 by IFNs}

IFN- $\beta$ and IFN- $\gamma$ were previously shown to upregulate the cosignaling molecule CD40 on monocytes $[24,25]$. We analyzed the simultaneous expression of CD40 and CD80 on monocytes, before and after IFNs treatment, by two-color direct immunofluorescence. Figure 
3 shows one representative case in which unstimulated monocytes (control) co-expressed CD40 and CD80 at low levels (25\%), and IFNs stimulation resulted in the appearance of a predominant $\mathrm{CD} 40^{+} \mathrm{CD} 80^{+}$subpopulation (around $70 \%$ ), suggesting that both molecules are regulated by IFNs in a coordinate way.

\subsection{IFN-mediated regulation of CD80 mRNA transcription}

We then investigated whether the IFN-driven increase in CD80 expression was at the transcriptional level. For this purpose, CD80 transcripts were examined in control and IFNtreated monocytes by RT-PCR. Whereas CD80 transcripts were undetectable, or only barely detectable in unstimulated monocytes, incubation with $1000 \mathrm{U} / \mathrm{mL}$ IFN- $\alpha$, IFN- $\beta$ or IFN- $\gamma$ for $18 \mathrm{~h}$ elicited a strong enhancement of these transcripts in the treated cells (Figure 4). This indicates that increased surface CD80 in response to IFNs is likely a result of increased CD80 mRNA transcription. In order to investigate the transcription factors involved, the expression profiles of IRF-1 and IRF-7 were examined. Whereas unstimulated monocytes expressed undetectable or low levels of IRF-1 and IRF-7 transcripts, treatment with both types of IFNs led to a dramatic stimulation of IRF-1 expression. In marked contrast, whereas IFN- $\gamma$ was ineffective, the IRF-7 transcript was strongly increased by type I interferons, as expected from previously reported study [21] (Figure 4). As controls, two genes whose expression is respectively regulated by IRF-7 [38-40] and IRF-1 [41], namely VEGF and CD40, were analysed in parallel. As shown in Figure 4, both types of IFNs elicited a small increase in CD40 transcripts whereas the level of VEGF mRNA was decreased by type I IFN but not by IFN- $\gamma$. Finally, trichostatin A (100 ng/mL), a known inhibitor of the ISGF3 complex involved in the IRF-7 transcription [41], did not alter the surface levels of CD80 in IFN-stimulated monocytes (data not shown). Together, our results suggest the involvement of IRF-1 in IFNenhanced expression of CD80 in human monocytes. 


\subsection{IFN- $\gamma$, but not IFN $\alpha / \beta$, upregulates CD80 in U937 cells through IRF-1 activation}

In order to confirm this role of IRF-1 in CD80 expression, similar experiments were

performed with the U937 cell line. The latter monocytic cell line is negative for CD40 but expresses CD80 [42, 43]. To ascertain whether IRF-1 or IRF-7 signalling was involved in CD80 upregulation induced by IFNs, we took advantage of our observation that IRF-1 and IRF-7 activations are specifically induced by one type IFN. Indeed, at variance with normal monocytes, IRF-1 mRNA expression was enhanced by IFN- $\gamma$ but not by IFN- $\alpha$ or IFN- $\beta$ (Figure 5A). Conversely, IRF-7 mRNA was increased by IFN- $\alpha / \beta$, but not by IFN- $\gamma$ (Figure 5A). Similar results were observed at the protein level (Figure 5B), although very faint amounts of IRF-1 were detected in lysates of U937 cells treated with type I IFNs. Of note, the stimulatory effect of IFN- $\gamma$ on IRF-1 synthesis was accompanied by CD80 upregulation at the mRNA (Figure 5A) and surface protein (Figure 5C) levels. Such enhancement of CD80 protein levels were maintained for $72 \mathrm{~h}$ in IFN- $\gamma$-treated U937 cells (data not shown). In contrast, IFN- $\alpha$ and IFN- $\beta$, which stimulate IRF-7, had no effect on CD80 mRNA (Figure 5A) and protein expression (Figure 5C). These results indicate that IRF-7 is not involved in the increased CD80 expression induced by IFNs, and demonstrate the implication of IRF-1 in CD80 enhancement in U937 cells. U937 cells were then transfected with siRNA for IRF-1 or scrambled siRNA as control for $24 \mathrm{~h}$, followed by IFN- $\gamma$ treatment for $18 \mathrm{~h}$. IFN- $\gamma$ could not stimulate CD80 expression in the cells transfected with IRF-1 siRNA, contrary to the cells transfected with the negative control (nc) siRNA (Figure 5C). Together, these data confirm that IRF-1 is involved in IFN-enhanced CD80 expression in human monocytic cells. They also suggest a defect in the signalling pathway of type I IFNs in U937 cells, inasmuch as these IFNs are unable to stimulate IRF-1 activation and CD80 expression. 


\subsection{Upregulation of CD80 on monocytes is not mediated by $T N \tilde{F} \alpha$}

The possibility that TNF- $\alpha$ could upregulate CD80 expression in monocytes was then investigated. In contrast to a previous report [31], no stimulatory effect of exogenously added TNF- $\alpha$ on CD80 expression was detected; the addition of TNF- $\alpha$ was also unable to potentiate the effect of IFN- $\gamma$ (Table 1). We next tested the possible implication of TNF- $\alpha$ endogenously released by monocytes in the basal expression of CD80. Monocytes were incubated for $18 \mathrm{~h}$ with neutralizing TNF- $\alpha$ antibody or with control goat IgG. As a control of TNF- $\alpha$ action, matrix metalloproteinase-9 (MMP-9) production was analysed in parallel. While MMP-9 production was inhibited in the presence of anti-TNF- $\alpha$, but not of goat IgG as isotype control, the levels of CD80 expression were not modified (Table 1). Together, these data strongly suggest that CD80 expression does not require TNF- $\alpha$ signalling and indicate that NF- $\mathrm{kb}$ signalling is unlikely to be involved.

\subsection{Differential upregulation of CD80 in AML cells according to FAB subtype}

We investigated the effects of IFNs on CD80 expression in leukemic cells from $12 \mathrm{AML}$ patients. Two groups of patients could be classified according to the spontaneous expression of CD80 on the leukemic cells and their modulation by IFNs. The first group $(n=7)$ of "non responders" is characterized by a weak basal level of CD80 (MFI <20) and an absence of upregulation by IFN- $\gamma$. The second group $(n=5)$ of "responders" display significant expression of CD80 (MFI >20) that markedly increases following IFN- $\gamma$ treatment (Figure 6A). IFN- $\tilde{\alpha}-\beta$ were also capable of enhancing CD80 expression in these "responders", albeit to a lower degree (not shown). Of importance, the "non responders" group included all FAB-M1/M2 patients and only one M5 patient. In contrast, the "responders" group included FAB-M4/M5 
patients and no M1/M2 patients. These subtypes of AML are defined by their distinct morphologic features : M1 and M2 represent respectively undifferentiated and differentiated myeloblastic leukemia ; M4 and M5 myelomonocytic and monocytic variants. When regrouped in M1/M2 on one hand and M4/M5 on the other hand, a significant difference in the repartition between "non responders" and "responders" was revealed (Table 2). As observed for normal monocytes, IFNs were capable of coinducing CD40 and CD80 surface expression, as exemplified for one representative M5 patient whose cells were stimulated with IFN- $\gamma($ Figure 6B).

We also examined CD80, IRF-1 and IRF-7 transcripts in "responders" and "non responders". As shown for one M5 responder, IRF-1, but not IRF-7 transcript was induced by IFN- $\gamma$ treatment and also, albeit to a lesser degree, by IFN- $\beta$ (Figure 7A); these inductions of IRF-1 were paralleled with that of CD80, inasmuch as upregulations of the CD80 transcript (Figure 7A) and cell surface protein (Figure 7B) were observed. In contrast, both types of IFNs were unable to stimulate IRF-1 and CD80 transcription in one representative case of a FAB/M1 patient (Figure 7A), even though type I IFN triggered IRF-7 expression, as in normal monocytes. Together, these results further emphasize that the increased CD80 surface expression by IFNs is associated with IRF-1 activation in AML cells.

\section{Discussion}

CD40 and CD80 are key molecules in the initiation of primary immune responses. In the present study, we show that type I and type II IFNs enhance CD40 and CD80 gene and protein expression in normal and tumoral monocytes. IFN-inducible CD40 gene expression was previously shown to be mediated by IRF-1 [27, 28]. A sequence motif search of MatInspector-Genomatix allowed us to identify in the CD80 gene (U33208) several 
consensus IRF-binding sites, including two IRF-7 sites. An IRF-7 binding site in LPSstimulated monocytic THP-1 cells was reported in CD80 transcript regulation by LPS [44]. We demonstrate here that IRF-1, but not IRF-7, is involved in IFN-induced CD80 upregulation in monocytes, as evidenced by the following observations: a) treatment of U937 cells with IFN-yactivated both IRF-1 and CD80 gene expression whereas type I IFN- $\alpha$ /Binduced IRF-7 without affecting CD80 transcript and protein levels; b) siRNA directed against IRF-1 impaired the IFN- $\gamma$-induced enhancement of CD80 levels; c) trichostatin A which inhibits the formation of ISGF3 complex [41] involved in the IRF-7 transcription, did not alter the surface levels of CD80 in IFN-stimulated monocytes. TNF- $\alpha$ activates the

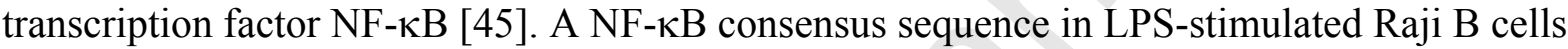
has been implicated in CD80 transcription.[46] Monocytes spontaneously release TNF- $\alpha$ [47] and the possibility that TNF- $\alpha$, through an autocrine loop, could enhance CD80 expression was thus considered. This hypothesis was ruled out, since TNF- $\alpha$ and neutralizing TNF- $\alpha$ antibody did not alter the levels of surface CD80 expression on monocytes, thus excluding the involvement of endogenous TNF- $\alpha$ in the stimulating action of IFNs on CD80. We observed that the expression of CD80 is heterogenous in 12 AML cases, with M4 and M5 blasts expressing higher constitutive levels of surface CD80 than in less differentiated AML cells with M1, M2 subtypes. Type I IFNs exhibit significant activity against AML in a xenograft murine model by inhibiting AML cell proliferation in vivo [48]. Discordant studies showed absent, low or overexpressed levels of IRF-1 transcripts in AML [49, 50]. Moreover, loss of one allele of the IRF-1 gene could be observed in some patients with AML [51]. In our study, IFNs preferentially increased CD80 transcript and protein levels in AML blasts with M4 and M5 FAB subtypes. Consistently, IFNs induced CD40/CD80 expression along with IRF-1 activation. Our results also suggest that AML blasts with M1 and M2 FAB 
subtypes could loose IFN- $\gamma$ sensitivity as a mechanism to evade immune detection. We recently found that the expression of CD80 on blasts from a patient with a myeloproliferative and myelodysplastic syndrome is increased upon IFNs stimulation (not shown). With regard to immunotherapy, the possible impact of IFNs on the expression profile of CD40 and CD80 costimulatory molecules on tumoral cells from patients with other hematological malignancies could be further investigated.

Matrix metalloproteinase-9 (MMP-9) is involved in tumor angiogenesis and tumor growth of AML cells [52]. We previously showed that IRF-1 activated by IFNs is essential for the repression of MMP-9 gene activation [37]. Along this line, we found a good correlation between CD80 upregulation and MMP-9 inhibition by IFNs in AML cells (not shown). It is therefore possible that simultaneous CD40-CD80 upregulation and MMP-9 downregulation by IFNs could have a detrimental effect on leukemic cells.

In conclusion, this study emphasizes the role of IRF-1 in the upregulation of CD40 and CD80 costimulatory molecules on normal and tumoral monocytes, and may help in the development of novel therapeutic strategies eliciting specific $\mathrm{T}$ cell responses to leukemia-associated antigens. Monitoring ex vivo the expression of CD80 on AML blasts and its modulation by IFNs could be of great interest to predict the patients who would be the more susceptible to benefit from such treatments.

\section{Acknowledgements}

This work was supported by grants from the Institut National de la Santé et de la Recherche Médicale, the Association pour la Recherche sur le Cancer (No.3473) and the Ligue Nationale Française contre le Cancer (Comité de Paris, grant $\mathrm{N}^{\circ} \mathrm{RS}$ 07/75-55). The authors thank Hoffman-La Roche (Basel, Switzerland) for supplying recombinant human IFN- $\alpha$, Ares- 
Serono (Geneva, Switzerland) for supplying recombinant human IFN- $\beta$ and the Etablissement Français du Sang (EFS, Paris) for supplying human blood.

\section{References}

1. Carreno BM, Carter LL and Collins M, Therapeutic opportunities in the B7/CD28 family of ligands and receptors. Curr Opin Pharmacol 5(4): 424-30, 2005.

2. Santilli F, Basili S, Ferroni P and Davi G, CD40/CD40L system and vascular disease. Intern Emerg Med 2(4): 256-68, 2007.

3. Wang S and Chen L, Co-signaling molecules of the B7-CD28 family in positive and negative regulation of T lymphocyte responses. Microbes Infect 6(8): 759-66, 2004.

4. Hirano N, Takahashi T, Ohtake S, Hirashima K, Emi N, Saito K, Hirano M, Shinohara K, Takeuchi M, Taketazu F, Tsunoda S, Ogura M, Omine M, Saito T, Yazaki Y, Ueda $\mathrm{R}$ and Hirai $\mathrm{H}$, Expression of costimulatory molecules in human leukemias. Leukemia 10(7): 1168-76, 1996.

5. Costello RT, Mallet F, Sainty D, Maraninchi D, Gastaut JA and Olive D, Regulation of CD80/B7-1 and CD86/B7-2 molecule expression in human primary acute myeloid leukemia and their role in allogenic immune recognition. Eur J Immunol 28(1): 90103, 1998.

6. Zheng Z, Takahashi M, Aoki S, Toba K, Liu A, Osman Y, Takahashi H, Tsukada N, Suzuki N, Nikkuni K, Furukawa T, Koike T and Aizawa Y, Expression patterns of costimulatory molecules on cells derived from human hematological malignancies. $J$ Exp Clin Cancer Res 17(3): 251-8, 1998.

7. Vollmer M, Li L, Schmitt A, Greiner J, Reinhardt P, Ringhoffer M, Wiesneth M, Dohner H and Schmitt M, Expression of human leucocyte antigens and co-stimulatory 
molecules on blasts of patients with acute myeloid leukaemia. Br J Haematol 120(6): $1000-8,2003$.

8. Li L, Schmitt A, Reinhardt P, Greiner J, Ringhoffer M, Vaida B, Bommer M, Vollmer M, Wiesneth M, Dohner H and Schmitt M, Reconstitution of CD40 and CD80 in dendritic cells generated from blasts of patients with acute myeloid leukemia. Cancer Immun 3: 8, 2003.

9. Ugurel S, Lindemann M, Schadendorf D and Grosse-Wilde H, Altered surface expression patterns of circulating monocytes in cancer patients: impaired capacity of T-cell stimulation? Cancer Immunol Immunother 53(11): 1051, 2004.

10. Chaux P, Moutet M, Faivre J, Martin F and Martin M, Inflammatory cells infiltrating human colorectal carcinomas express HLA class II but not B7-1 and B7-2 costimulatory molecules of the T-cell activation. Lab Invest 74(5): 975-83, 1996.

11. Ward RC and Kaufman HL, Targeting costimulatory pathways for tumor immunotherapy. Int Rev Immunol 26(3-4): 161-96, 2007.

12. Mutis T, Schrama E, Melief CJ and Goulmy E, CD80-Transfected acute myeloid leukemia cells induce primary allogeneic T-cell responses directed at patient specific minor histocompatibility antigens and leukemia-associated antigens. Blood 92(5): $1677-84,1998$

13. Stripecke R, Cardoso AA, Pepper KA, Skelton DC, Yu XJ, Mascarenhas L, Weinberg KI, Nadler LM and Kohn DB, Lentiviral vectors for efficient delivery of CD80 and granulocyte-macrophage- colony-stimulating factor in human acute lymphoblastic leukemia and acute myeloid leukemia cells to induce antileukemic immune responses. Blood 96(4): 1317-26, 2000. 
14. Notter M, Willinger T, Erben U and Thiel E, Targeting of a B7-1 (CD80) immunoglobulin $\mathrm{G}$ fusion protein to acute myeloid leukemia blasts increases their costimulatory activity for autologous remission T cells. Blood 97(10): 3138-45, 2001.

15. Parmar S and Platanias LC, Interferons: mechanisms of action and clinical applications. Curr Opin Oncol 15(6): 431-9, 2003.

16. Borden EC, Review: Milstein Award lecture: interferons and cancer: where from here? J Interferon Cytokine Res 25(9): 511-27, 2005.

17. Obeid D and Bauvois B, Interferons: mechanisms, biological activities and survey of their use in human disease. Current Bioactive Compounds 2: 431-44, 2006.

18. Kalvakolanu DV, Alternate interferon signaling pathways. Pharmacol Ther 100(1): 129, 2003.

19. Li Y, Srivastava KK and Platanias LC, Mechanisms of type I interferon signaling in normal and malignant cells. Arch Immunol Ther Exp (Warsz) 52(3): 156-63, 2004.

20. Schroder K, Hertzog PJ, Ravasi T and Hume DA, Interferon-gamma: an overview of signals, mechanisms and functions. J Leukoc Biol 75(2): 163-89, 2004.

21. Paun A and Pitha PM, The IRF family, revisited. Biochimie 89(6-7): 744-53, 2007.

22. Langer JA, Cutrone EC and Kotenko S, The Class II cytokine receptor (CRF2) family: overview and patterns of receptor-ligand interactions. Cytokine Growth Factor Rev 15(1): 33-48, 2004.

23. Marijanovic Z, Ragimbeau J, van der Heyden J, Uze G and Pellegrini S, Comparable potency of IFNalpha2 and IFNbeta on immediate JAK/STAT activation but differential down-regulation of IFNAR2. Biochem J 407(1): 141-51, 2007.

24. Alderson MR, Armitage RJ, Tough TW, Strockbine L, Fanslow WC and Spriggs MK, CD40 expression by human monocytes: regulation by cytokines and activation of monocytes by the ligand for CD40. J Exp Med 178(2): 669-74, 1993. 
25. Marckmann S, Wiesemann E, Hilse R, Trebst C, Stangel M and Windhagen A, Interferon-beta up-regulates the expression of co-stimulatory molecules CD80, CD86 and CD40 on monocytes: significance for treatment of multiple sclerosis. Clin Exp Immunol 138(3): 499-506, 2004.

26. Nguyen VT and Benveniste EN, Critical role of tumor necrosis factor-alpha and NFkappa B in interferon-gamma -induced CD40 expression in microglia/macrophages. $J$ Biol Chem 277(16): 13796-803, 2002.

27. Wagner AH, Gebauer M, Pollok-Kopp B and Hecker M, Cytokine-inducible CD40 expression in human endothelial cells is mediated by interferon regulatory factor-1. Blood 99(2): 520-5, 2002.

28. Zhao Z, Qian Y, Wald D, Xia YF, Geng JG and Li X, IFN regulatory factor-1 is required for the up-regulation of the CD40-NF-kappa B activator 1 axis during airway inflammation. J Immunol 170(11): 5674-80, 2003.

29. Freedman AS, Freeman GJ, Rhynhart K and Nadler LM, Selective induction of B7/BB-1 on interferon-gamma stimulated monocytes: a potential mechanism for amplification of T cell activation through the CD28 pathway. Cell Immunol 137(2): 429-37, 1991.

30. Creery WD, Diaz-Mitoma F, Filion L and Kumar A, Differential modulation of B7-1 and B7-2 isoform expression on human monocytes by cytokines which influence the development of T helper cell phenotype. Eur J Immunol 26(6): 1273-7, 1996.

31. Clavreul A, D'Hellencourt C L, Montero-Menei C, Potron G and Couez D, Vitamin D differentially regulates B7.1 and B7.2 expression on human peripheral blood monocytes. Immunology 95(2): 272-7, 1998.

32. Bauvois B, Van Weyenbergh J, Rouillard D and Wietzerbin J, TGF-beta 1-stimulated adhesion of human mononuclear phagocytes to fibronectin and laminin is abolished by 
IFN-gamma: dependence on alpha 5 beta 1 and beta 2 integrins. Exp Cell Res 222(1): 209-17, 1996.

33. Bauvois B, Dumont J, Mathiot C and Kolb JP, Production of matrix metalloproteinase-9 in early stage B-CLL: suppression by interferons. Leukemia 16(5): 791-8, 2002.

34. Yeow WS, Au WC, Juang YT, Fields CD, Dent CL, Gewert DR and Pitha PM, Reconstitution of virus-mediated expression of interferon alpha genes in human fibroblast cells by ectopic interferon regulatory factor-7. J Biol Chem 275(9): 6313$20,2000$.

35. Park HY, Park JY, Kim JW, Lee MJ, Jang MJ, Lee SY, Baek DW, Park YM, Lee SW, Yoon S, Bae YS and Kwak JY, Differential expression of dendritic cell markers by all-trans retinoic acid on human acute promyelocytic leukemic cell line. Int Immunopharmacol 4(13): 1587-601, 2004.

36. Ruiz-Ruiz C, Ruiz de Almodovar C, Rodriguez A, Ortiz-Ferron G, Redondo JM and Lopez-Rivas A, The up-regulation of human caspase- 8 by interferon-gamma in breast tumor cells requires the induction and action of the transcription factor interferon regulatory factor-1. J Biol Chem 279(19): 19712-20, 2004.

37. Sanceau J, Boyd DD, Seiki M and Bauvois B, Interferons inhibit tumor necrosis factor-alpha-mediated matrix metalloproteinase-9 activation via interferon regulatory factor-1 binding competition with NF-kappa B. J Biol Chem 277(38): 35766-75, 2002.

38. Rosewicz S, Detjen K, Scholz A and von Marschall Z, Interferon-alpha: regulatory effects on cell cycle and angiogenesis. Neuroendocrinology 80 Suppl 1: 85-93, 2004.

39. Takano S, Kamiyama H, Tsuboi K and Matsumura A, Angiogenesis and antiangiogenic therapy for malignant gliomas. Brain Tumor Pathol 21(2): 69-73, 2004. 
40. Wu WZ, Sun HC, Shen YF, Chen J, Wang L, Tang ZY, Iliakis G and Liu KD, Interferon alpha 2a down-regulates VEGF expression through PI3 kinase and MAP kinase signaling pathways. J Cancer Res Clin Oncol 131(3): 169-78, 2005.

41. Genin P, Morin P and Civas A, Impairment of interferon-induced IRF-7 gene expression due to inhibition of ISGF3 formation by trichostatin A. J Virol 77(12): 7113-9, 2003

42. Reischl IG, Pollabauer EM, Peiritsch S, Schlager S, Gladstone P, Vooijs WC, Woisetschlager M and Mudde GC, The 'monocytic' cell line I937 displays typical B cell characteristics. Immunol Lett 49(1-2): 127-31, 1996.

43. Stonehouse TJ, Woodhead VE, Herridge PS, Ashrafian H, George M, Chain BM and Katz DR, Molecular characterization of U937-dependent T-cell co-stimulation. Immunology 96(1): 35-47, 1999.

44. Lim W, Gee K, Mishra S and Kumar A, Regulation of B7.1 costimulatory molecule is mediated by the IFN regulatory factor-7 through the activation of JNK in lipopolysaccharide-stimulated human monocytic cells. J Immunol 175(9): 5690-700, 2005.

45. Chen G and Goeddel DV, TNF-R1 signaling: a beautiful pathway. Science 296(5573): 1634-5, 2002.

46. Zhao J, Freeman GJ, Gray GS, Nadler LM and Glimcher LH, A cell type-specific enhancer in the human B7.1 gene regulated by NF-kappaB. $J$ Exp Med 183(3): 77789, 1996.

47. Nguyen J, Knapnougel P, Lesavre P and Bauvois B, Inhibition of matrix metalloproteinase- 9 by interferons and TGF-beta 1 through distinct signalings accounts for reduced monocyte invasiveness. FEBS Lett 579(25): 5487-93, 2005. 
48. Benjamin R, Khwaja A, Singh N, McIntosh J, Meager A, Wadhwa M, Streck C, Ng C, Davidoff AM and Nathwani AC, Continuous delivery of human type I interferons (alpha/beta) has significant activity against acute myeloid leukemia cells in vitro and in a xenograft model. Blood 109(3): 1244-7, 2007.

49. Schmidt M, Nagel S, Proba J, Thiede C, Ritter M, Waring JF, Rosenbauer F, Huhn D, Wittig B, Horak I and Neubauer A, Lack of interferon consensus sequence binding protein (ICSBP) transcripts in human myeloid leukemias. Blood 91(1): 22-9, 1998.

50. Guzman ML, Upchurch D, Grimes B, Howard DS, Rizzieri DA, Luger SM, Phillips GL and Jordan CT, Expression of tumor-suppressor genes interferon regulatory factor 1 and death-associated protein kinase in primitive acute myelogenous leukemia cells. Blood 97(7): 2177-9, 2001.

51. Boultwood J, Fidler C, Lewis S, MacCarthy A, Sheridan H, Kelly S, Oscier D, Buckle VJ and Wainscoat JS, Allelic loss of IRF1 in myelodysplasia and acute myeloid leukemia: retention of IRF1 on the $5 \mathrm{q}$ - chromosome in some patients with the $5 \mathrm{q}$ syndrome. Blood 82(9): 2611-6, 1993.

52. Klein G, Vellenga E, Fraaije MW, Kamps WA and de Bont ES, The possible role of matrix metalloproteinase (MMP)-2 and MMP-9 in cancer, e.g. acute leukemia. Crit Rev Oncol Hematol 50(2): 87-100, 2004.

\section{Figure Legends}


Figure 1. Flow cytometry analysis of the expression of CD80 on monocytes before and after treatment with IFNs

Isolated monocytes $\left(1 \times 10^{6}\right.$ cells $\left./ \mathrm{mL}\right)$ were cultured for $18 \mathrm{~h}(\mathrm{~A})$ or $24 \mathrm{~h}(\mathrm{~B})$ in the absence or presence of IFNs (1000 U/mL). (A) Representative histograms of monocytes stained with anti-CD80-PE (black line) or its isotype mIgG1-PE (broken line) and then analyzed by flow cytometry. (B) Data are calculated as CD80 median fluorescence intensity obtained by subtracting the peak channel number of the negative control from the peak channel number of the corresponding antibody and represent the mean of 7 separate experiments $\pm \mathrm{SD} . P=$ 0.0001 compared with control.

Figure 2. Time- and dose-responses of the upregulation of CD80 expression by IFNs (A) Monocytes $\left(1 \times 10^{6}\right.$ cells $\left./ \mathrm{mL}\right)$ were cultured for various time periods with $1000 \mathrm{U} / \mathrm{mL}$ IFNs. (B) Monocytes $\left(1 \times 10^{6}\right.$ cells $\left./ \mathrm{mL}\right)$ were cultured in the absence or presence of increasing concentrations of IFNs (10-2000 U/mL) for $24 \mathrm{~h}$. Cells were then assessed for CD80 expression by flow cytometry. Data from one experiment representative of 3 are calculated as CD80 median fluorescence intensity.

Figure 3. Cell surface CD40 and CD80 expression patterns of monocytes before and after IFN treatment

Monocytes $\left(1 \times 10^{6}\right.$ cells $\left./ \mathrm{mL}\right)$ were cultured for $24 \mathrm{~h}$ with $1000 \mathrm{U} / \mathrm{mL}$ IFNs. Cells were stained with mIgG1-FITC/mIgG1-PE (left panels) or anti-CD40-FITC/anti-CD80-PE (right panels) and then examined by flow cytometry. The $\mathrm{x}$-axis shows log green fluorescence and $\mathrm{y}$-axis shows red fluorescence. The percentage of specifically stained $\mathrm{CD} 40^{+}$cells, $\mathrm{CD} 80^{+}$cells and 
$\mathrm{CD} 40^{+} \mathrm{CD} 80^{+}$cells is indicated respectively in the lower right, upper left and upper right quadrants of each plot.

Figure 4. Effects of IFNs on CD80, IRFs, CD40 and VEGF transcripts in monocytes The cDNAs from a representative monocyte sample cultured for $18 \mathrm{~h}$ with or without 1000 $\mathrm{U} / \mathrm{mL}$ of the various IFNs were used as templates for PCR reactions using specific primers for CD80, IRF-1, IRF-7, CD40, VEGF or $\beta 2$-microglobulin (internal standard), as described in Materials and Methods. PCR products were run on 2\% agarose gels. The intensity of the bands of the various transcripts were compared using the the NIH Image 1.63 software after acquisition in an Appligen densitometer (Oncor) and normalised with $\beta 2$-microglobulin. Values represent the ratio of $\mathrm{VEGF} / \beta 2-\mathrm{m}$ and $\mathrm{CD} 40 / \beta 2-\mathrm{m}$ mRNAs.

Figure 5. Effects of IFNs and IRF-1 siRNA on the expression of CD80 in U937 cells (A) RT-PCR analysis of CD80, IRF-1, IRF-7 and $\beta 2$-microglobulin transcripts after U937 cell treatment $\left(2 \times 10^{5} / \mathrm{mL}\right)$ with IFNs $(1000 \mathrm{U} / \mathrm{mL})$ for $18 \mathrm{~h}$. (B) Whole cell lysates $(50 \mu \mathrm{g}$ of proteins) obtained from U937 cells treated with IFNs $(1000 \mathrm{U} / \mathrm{mL})$ for $24 \mathrm{~h}$, were separated by $12 \%$ SDS-PAGE. Western blots were probed with Abs against IRF-1, IRF-7 or actin. (C) Surface CD80 staining of U937 cells treated with IFNs $1000 \mathrm{U} / \mathrm{mL}$ for $18 \mathrm{~h}$, before or after transfection with IRF-1 specific siRNA or negative control (nc) siRNA as described in Materials and Methods. C80-PE (black line) or its isotype mIgG1-PE (broken line).

Figure $6:$ Effects of IFNs on the surface CD40 and CD80 levels in AML cells

Blasts ( $1 \times 10^{6}$ cells $\left./ \mathrm{mL}\right)$ from 12 AML patients with FAB M1 (4), M2 (2), M5 (4) and M4 (2) were cultured in the absence or presence of IFN- $\gamma(1000 \mathrm{U} / \mathrm{mL})$. Following $24 \mathrm{~h}$, cells were 
then stained with anti-CD40-FITC, anti-CD80-PE or their isotypes and then analyzed by flow cytometry. (A) Surface CD80 staining of AML cells. Results are expressed as CD80 median fluorescence intensity after subtraction of background values for control isotype. (B) Representative cytograms with blasts from one patient with FAB M5 subtype are shown.

Figure 7. Effects of IFNs on CD80 transcript and protein levels in AML cells

Blasts $\left(1 \times 10^{6}\right.$ cells $\left./ \mathrm{mL}\right)$ from 2 patients with AML, M5 (responder) or M1 (non responder), were cultured in the absence or presence of IFNs $(1000 \mathrm{U} / \mathrm{mL})$. (A) RT-PCR analysis of CD80, IRF-1, IRF-7 and $\beta$ 2-microglobulin transcripts after cell treatment for $18 \mathrm{~h}$. (B) Histograms of blasts from the M5 responder, stained with anti-C80-PE (black line) or its isotype mIgG1-PE (broken line) and then analyzed by flow cytometry. 
Table 1. TNF- $\alpha$ does not regulate CD80 expression in monocytes

\begin{tabular}{|l|l|l|}
\hline Treatment & $\begin{array}{l}\text { Percent of CD80 positive cells } \\
\text { (median fluorescence intensity) }\end{array}$ & $\begin{array}{l}\text { MMP-9 production } \\
\mathrm{pg} / 10^{6} \text { cells }\end{array}$ \\
\hline Unstimulated & $54(41)$ & 2750 \\
+ TNF- $\alpha$ & $59(43)$ & nd \\
+ IFN- $\gamma$ & $80(86)$ & 250 \\
+ TNF- $\alpha+$ IFN- $\gamma$ & $80(91)$ & nd \\
+ goat IgG & $58(59)$ & 2320 \\
+ anti-TNF- $\alpha$ & $50(45)$ & \\
\hline
\end{tabular}

Monocytes, cultured for $24 \mathrm{~h}$ in the absence or presence of TNF- $\alpha(10 \mu \mathrm{g} / \mathrm{mL})$, IFN- $\gamma(1000$ $\mathrm{U} / \mathrm{mL})$, TNF- $\alpha(10 \mu \mathrm{g} / \mathrm{mL})+\mathrm{IFN}-\gamma(1000 \mathrm{U} / \mathrm{mL})$, goat IgG $(10 \mu \mathrm{g} / \mathrm{mL})$ or neutralizing goat anti-TNF- $\alpha \operatorname{IgG}(10 \mu \mathrm{g} / \mathrm{mL})$ were then tested for expression of surface CD80 by flow cytometry and for MMP-9 production, as measured with a specific ELISA (R\&D). Flow cytometry results are given as \% of CD80 positive cells and mean fluorescence intensity (brackets). nd, not determined. An experiment representative of two is shown. 
Table 2 : Subtypes of AML patients differ according to their CD80 expression

\begin{tabular}{|l|l|l|l|}
\hline Patients & M1/M2 & M4/M5 & total \\
\hline non responders & 6 & 1 & 7 \\
\hline responders & 0 & 5 & 5 \\
\hline total & 6 & 6 & 12 \\
\hline
\end{tabular}

AML patients were classified in two groups according to their FAB subtype : M1/M2 and M4/M5. For each group, the numbers of « non responders » (spontaneous expression of CD80 with a MFI $<20$ and absence of upregulation by IFN- $\gamma$ ) and « responders » (spontaneous expression of CD80 with a MFI $>20$ and upregulation by IFN- $\gamma$ ) were determined. Statistical analysis was performed using the Chi square test that gave a value of $\mathrm{c}=8.6 \quad(\mathrm{p} \leq 0.001)$. 
FIGURE 1
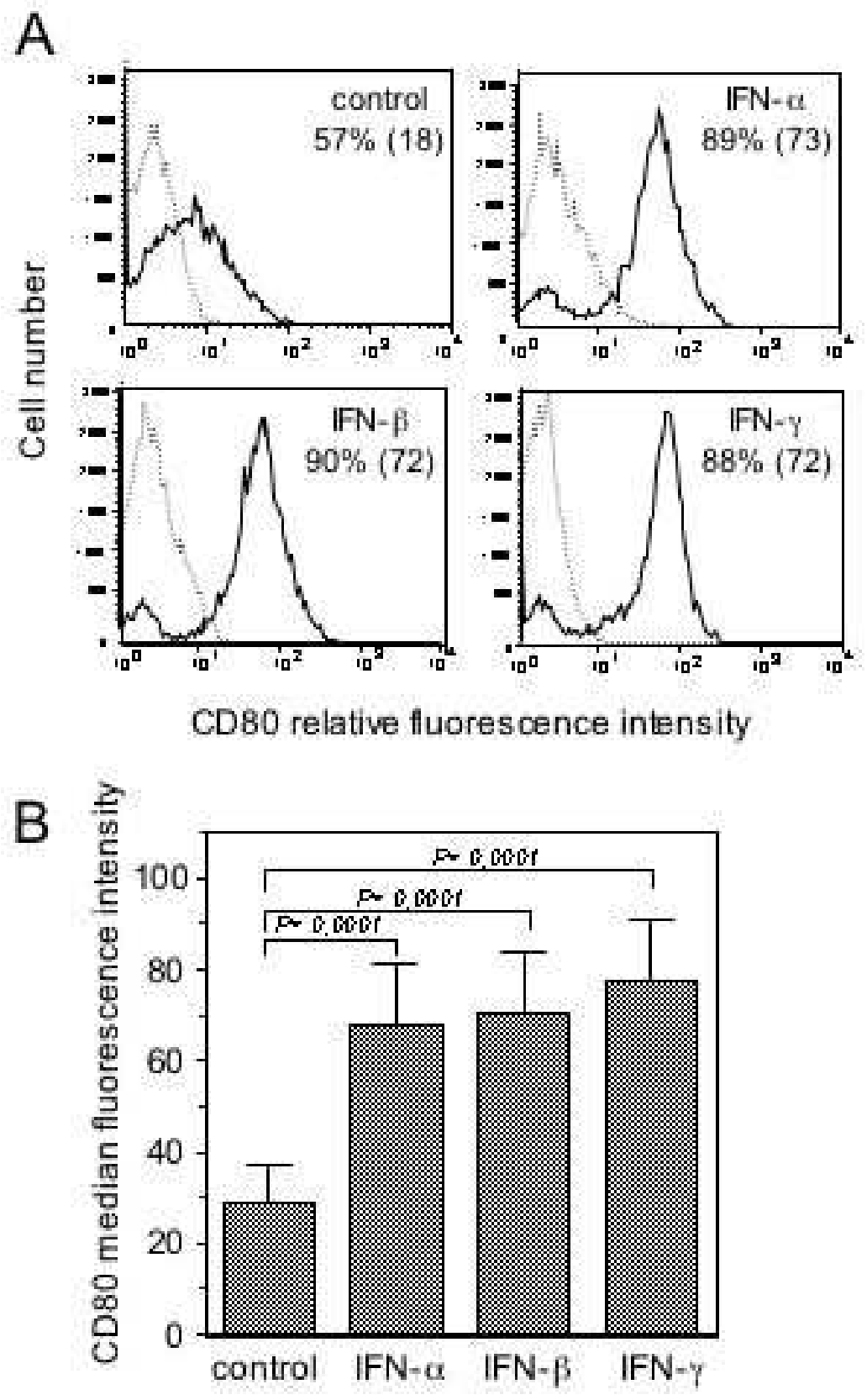
FIGURE 2
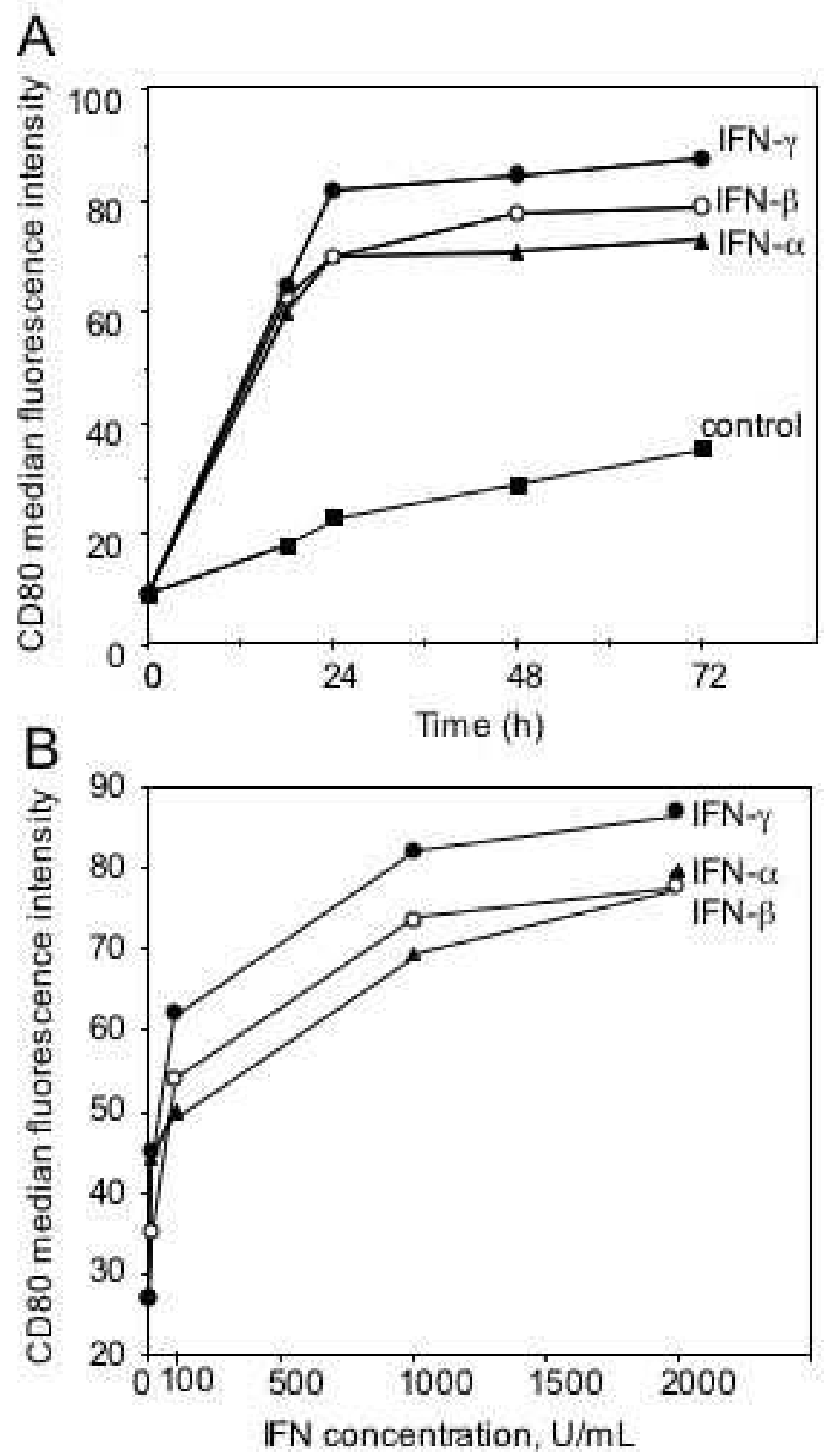


\section{FIGURE 3}
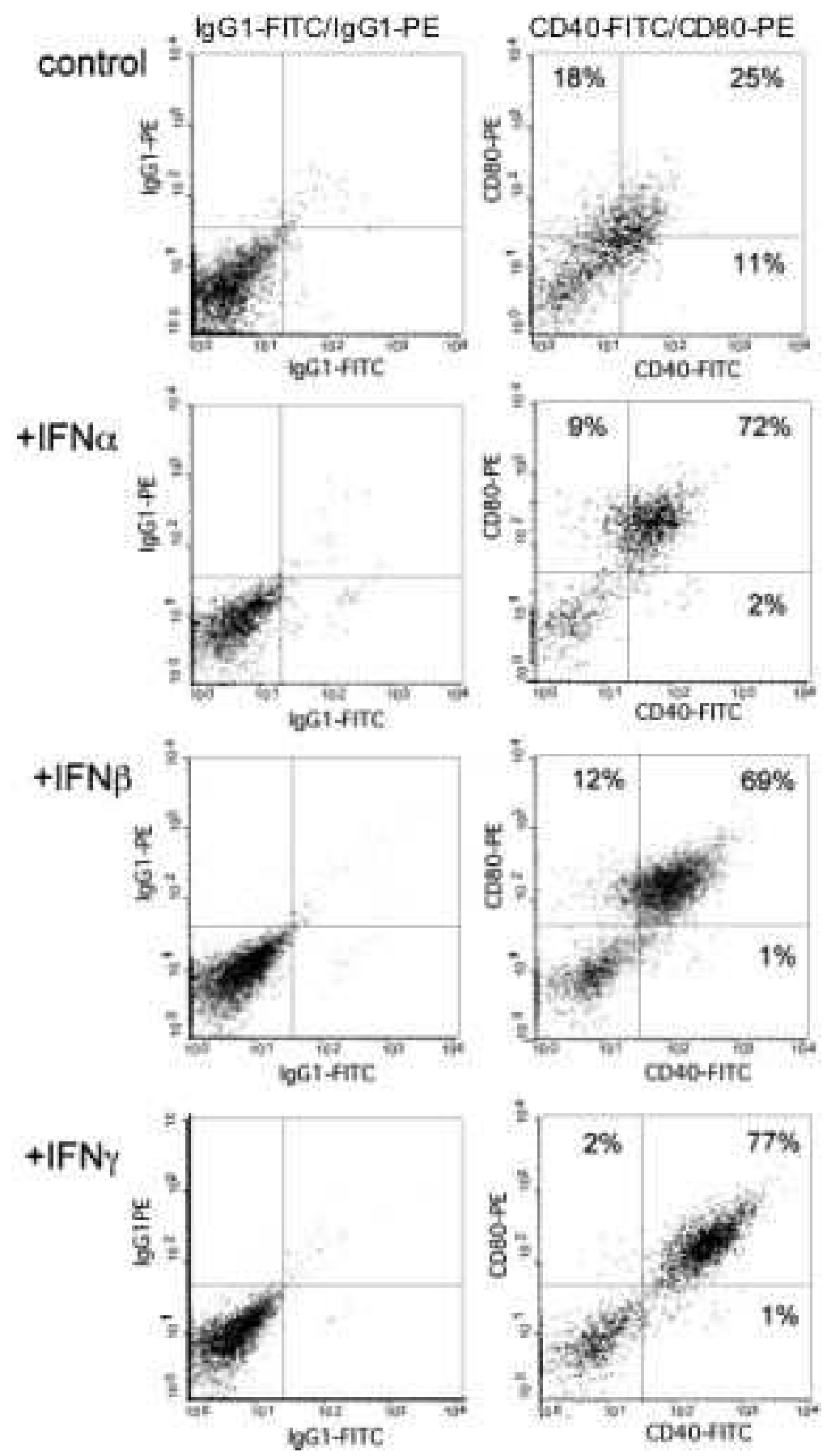


\section{FIGURE 4 \\ FIGURE 4}
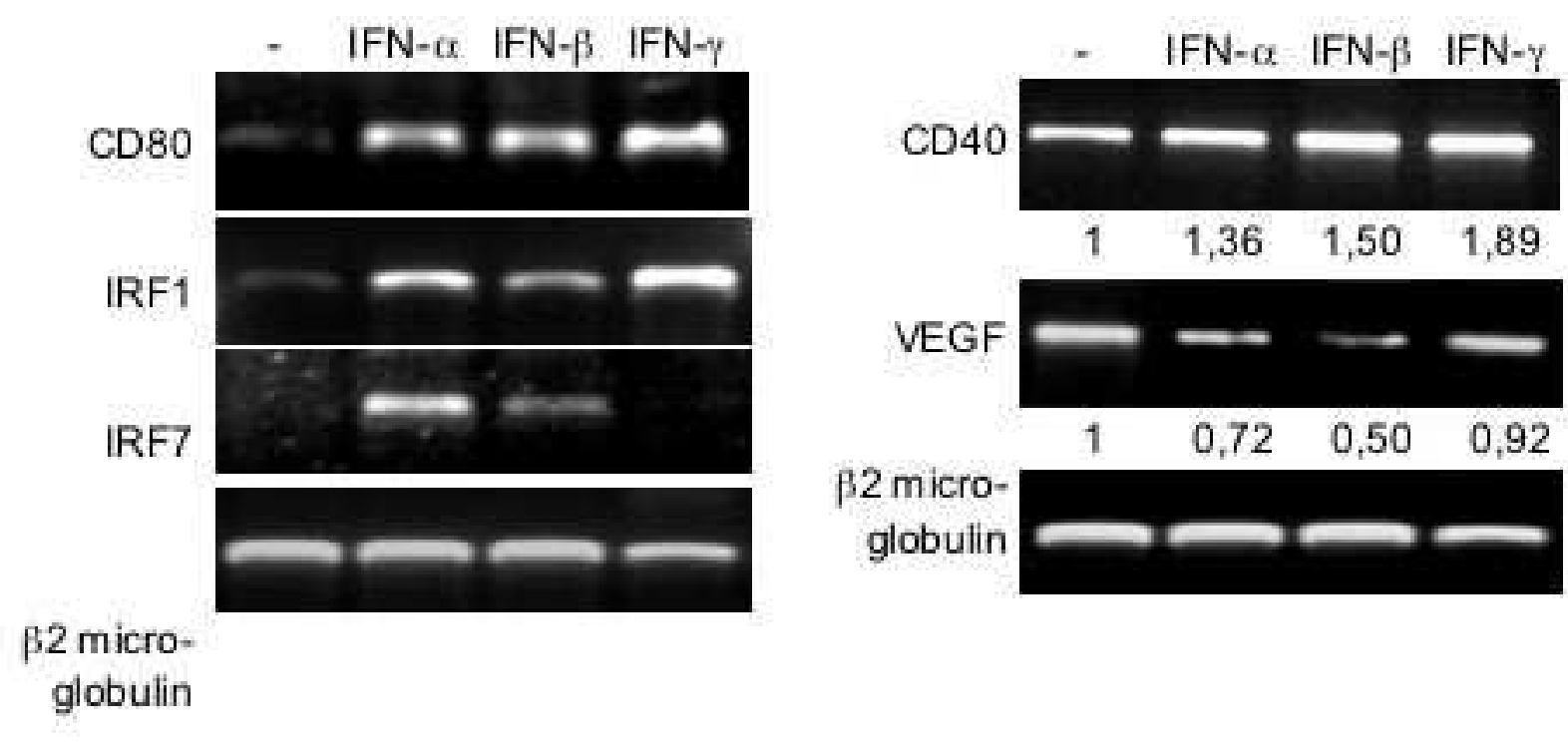

globulin

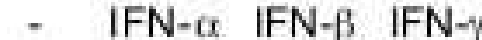

globuitin
- IFN- $\alpha$, IFN- $\beta$ IFN- $\gamma$

$\begin{array}{llll}1 & 1,36 & 1,50 & 1,89\end{array}$

$\begin{array}{llll}1 & 0,72 & 0,50 & 0,92\end{array}$

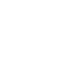
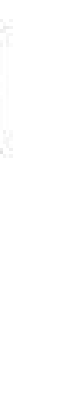

(1) 


\section{FIGURE 5}
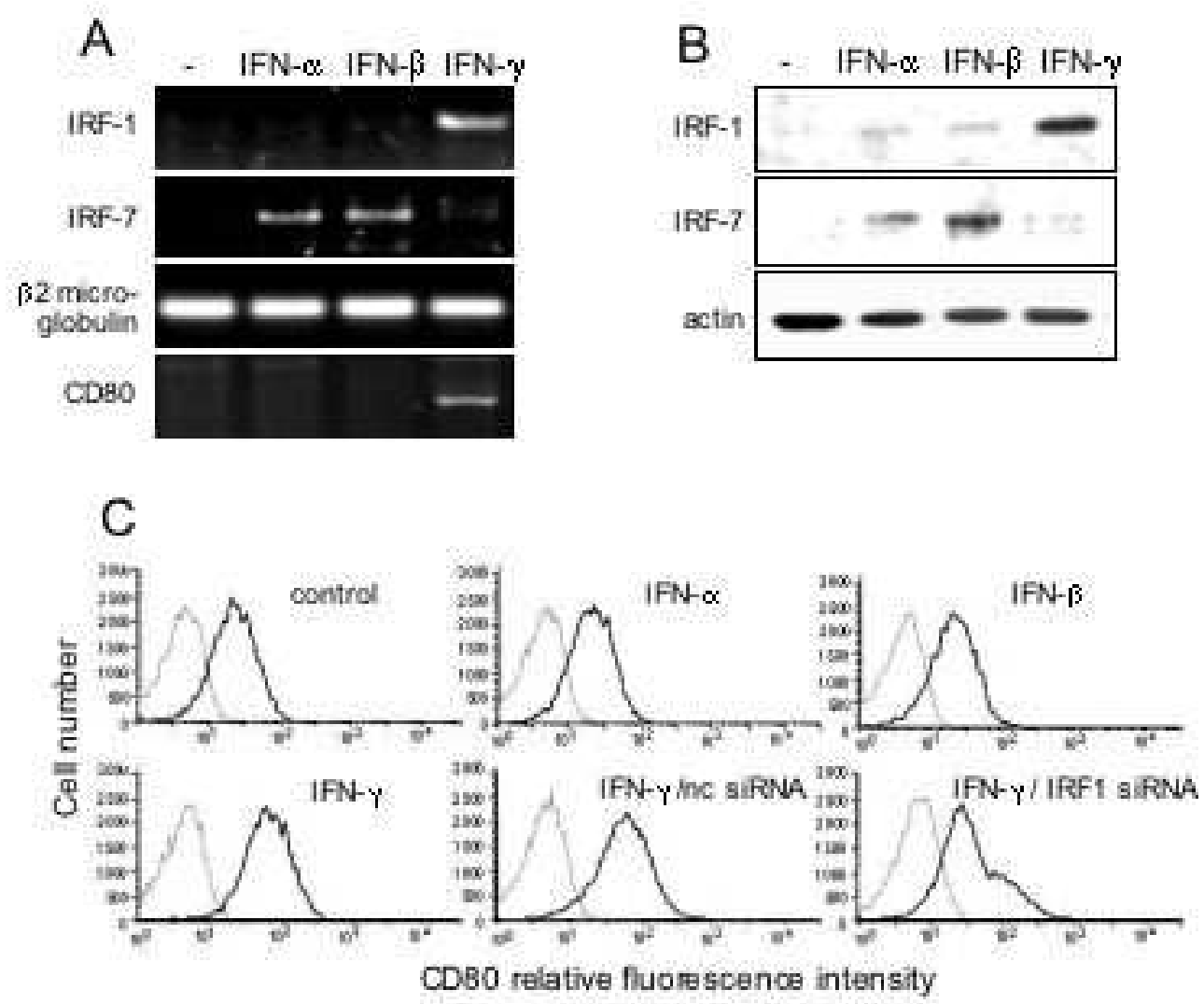
FIGURE 6
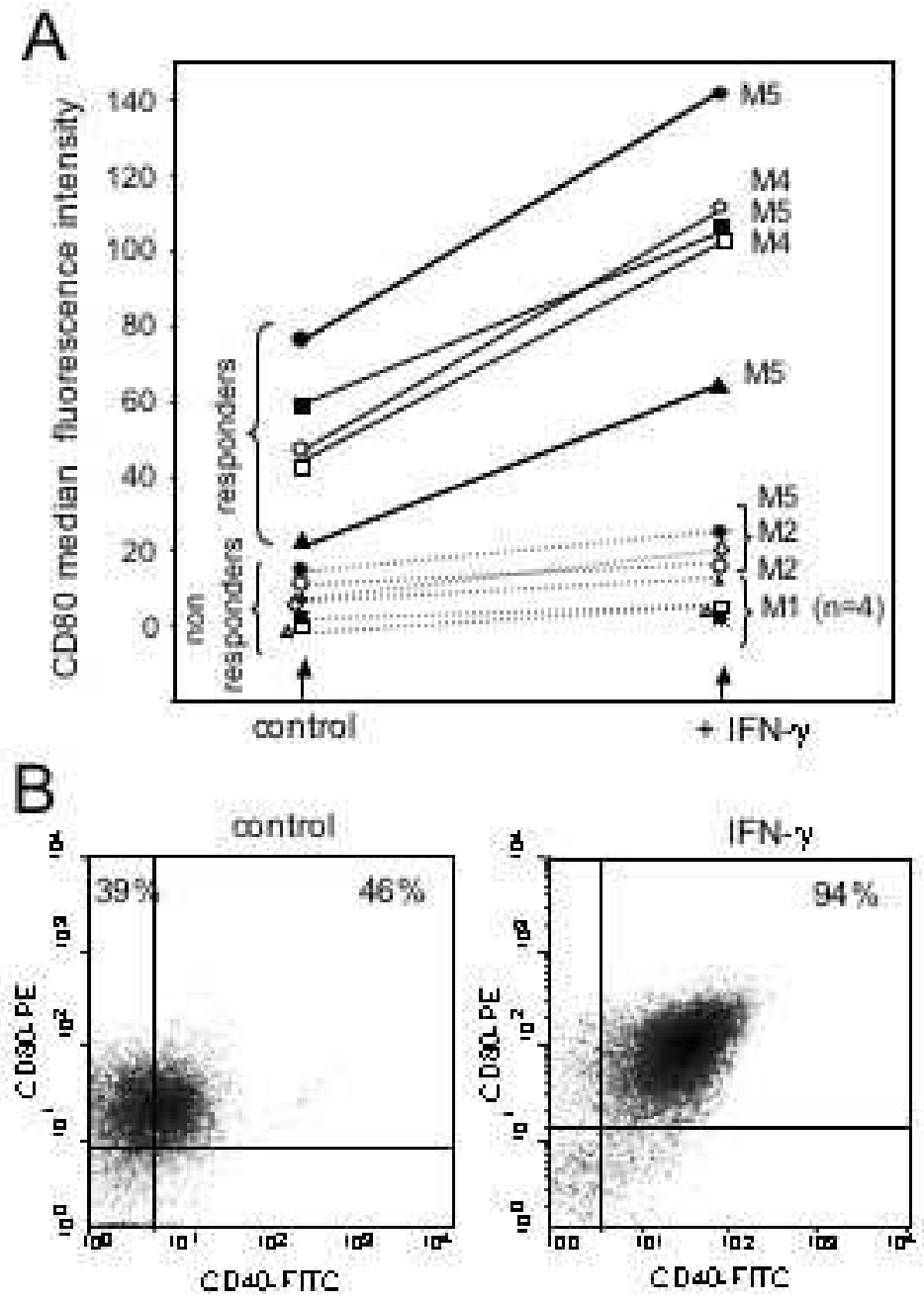
FIGURE 7
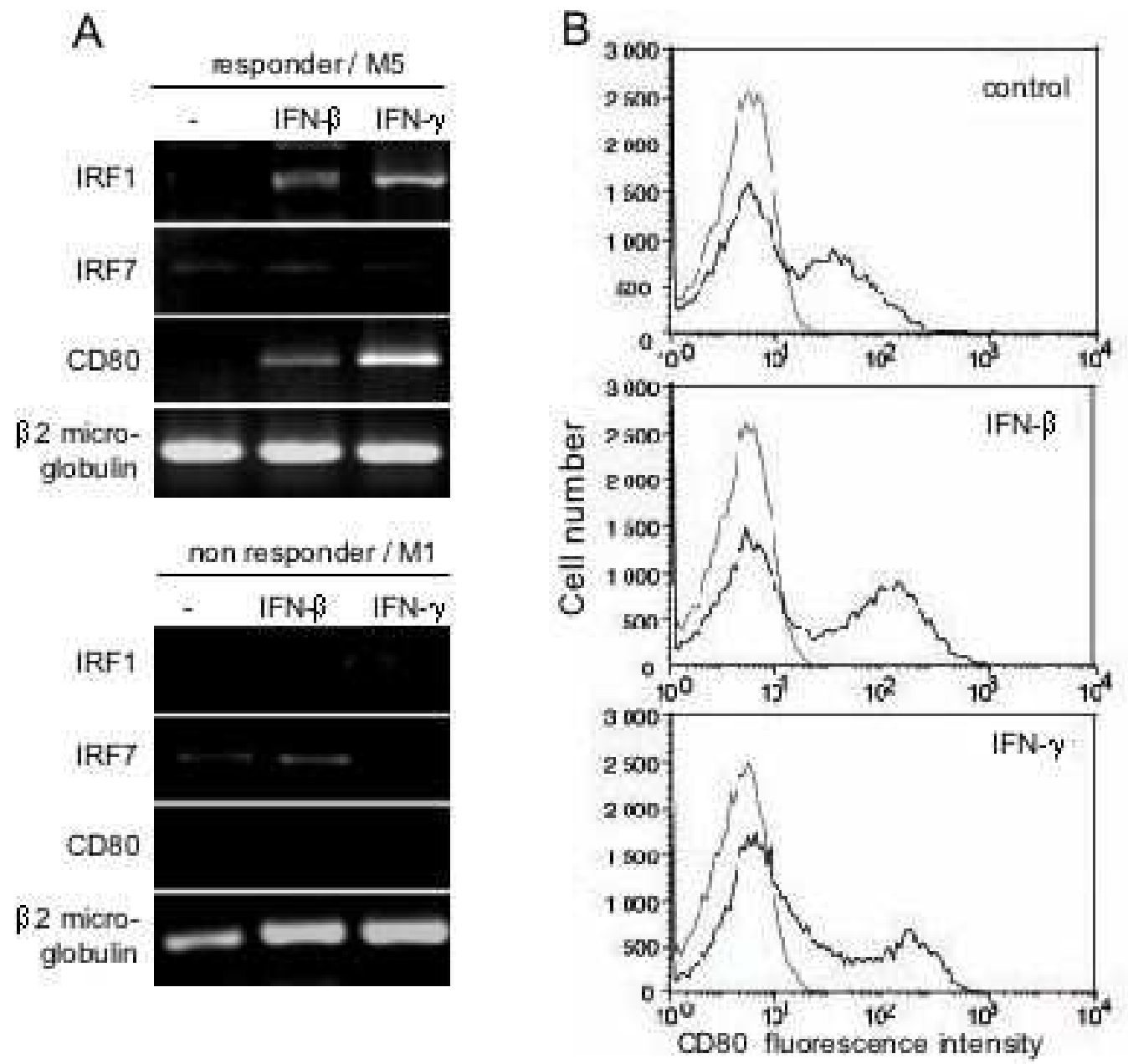